conclusions which Duke-Elder and Kinsey draw from their studies are compatible with the details of structure and organisation which we have found in the ocular tissues.

\title{
REFERENCES
}

1. Duke-Elder and Davson (1943).-Brit. Jl. Ophthal., Vol. XXVII, p. 431.

2. KINŚey, Grant and Cogan (1942).-Arch. Ophthal., Vol. XXVII, p. 242. KINSEY, GRANT and COGAN, Livingood and CURTIS (1942).-Arch. Ophthal., Vol XXVII, p. 1126.

KINSEY and GRANT (1942).- $J l$. Gen. Physiol., Vol. XXVI, pp. 119, 131.

3. FriedenWALd and Stiehler (1938). -Arch. Ophthal., Vol. XX, p. 761

FRIEDENWALD, BUSCHKE and MICHEL (1943). -Arch. Ophthal., Vol. XXIX, p. 535.

4. Bethe and Toropoff (1915).-Zeitschr. f. Phys. Chem., Vol. XXXIX, p. 597.

5. DuKE-Elder, Quilílan and DavSON (1940):-Brit.Ji. Ophthal., Vol, XXIV,

p. 421 .
DAvSon and WeLd (1941)'-Amer. Jl. Physiol., Vol. CXXXIV, p. 1.

BenhaM, G. H., DUKE-Elder, W. S. and Hodgson, T. H. (1938),- $J l$. Physiol.,IVol. XCII, p. 355.

6. WAlker, A. M. (1933).-Jl. Biol. Chem:, Vol. CI, p. 269.

7. AdLER, F. H. (1933). -Arch. Ophthal., Vol. X, p. 11.

8. BENHAM, G. H. (1937).-Biochem: Jl., Vol. XXXI, p. 1157.

9. Mehrtens and NeWman (1933).-Arch. Neurol. and Psych., Vol. XXX, p. 1092.

10. Goldberg (1937).-Skand. Arch. Physiol., Vol. LXXVII, p. 179.

Fleming and Stotz (1935).-Arch. Neurol. and Pysch., Vol. XXXIII p. 492. - (1936).-Arch. Neurol. and Psych., Vol. XXXV, p. 117.

11. DUKe-ElDER; W. S. (1926).-Brit. Jl. Ophthal., Vol. X, p. 513.

12. FriedenWaLd, J. S. (1936).-Arch. Ophthal., Vol. XVI, p. 65.

\section{MUCOCELE OF MAXILLARY ANTRUM}

BY

\section{G. E. DoDDS}

WEST AFRICAN MEDTCAL SERVICE

THE patient in this case presented himself at a native dispensary in the "bush" in Southern Nigeria.

All that could be done was to examine, photograph and endeavour to persuade him to come to hospital. Nothing further was attempted-as it was hoped that at some future date transillumination, nasal examination, X-ray and operation could be carried out.

At the time the case was seen it would have been quite easy to insert an exploratory needle through the skin of the lower eyelid and doubtless a thick gelatinous flutid could have been aspirated.

Such a procedure would have undoubtedly encouraged the patient to think that a cure had been effected or would eventuate in time, and so the possibility of further enquiries would have been indefinitely postponed. A knowledge of local psychology is essential for the benefit of all concerned, and curiosity must be tempered with discretion if medical secrets are to be exposed. 

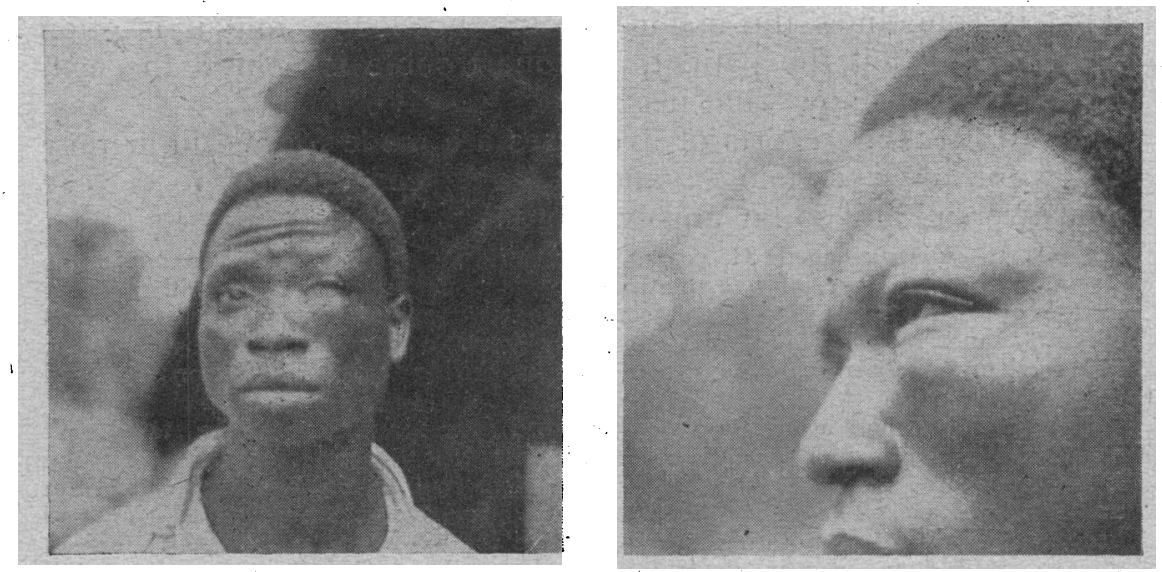

Cases of mucocele in Nigerians have been seen by the writer in connection with ethmoidal cells and the frontal sinus. As no case of this type has been seen, it may prove of interest.

"In Diseases of the Nose, Throat and Ear," by A. Logan Turner, Ed., 1936, the following statement appears on page 96. "It is doubtful if a parallel condition (i.e., mucocele), has been found in the antrum." The swelling in this case was situated just above the lower margin of the orbit, and could be palpated for a certain distance into the orbit. It gave the typical sensation of a fluidcontaining cyst, and was but slightly moveable from side to side. The globe was displaced upwards. Apart from disfigurement and diplopia the patient suffered little inconvenience.

His photograph belies his mental outlook - he was not worried; he had no pain; it is unlikely for those reasons that he will trouble to come the 15 miles or so to hospital.

It is regretted that definite proof that this is a mucocele of the antrum has not, so far, been obtained in this case.

\title{
RETRO-BULBAR NEURITIS (Five Cases) due to Para-nasal Sinusitis
}

\author{
BY \\ ROSA FORD \\ LONDON
}

WE see many eyes that are quite normal, with poor, sometimes extremely defective, sight. If this blindness is in only one eye, or in both with no hemianopia, the lesion must lie in one or both optic nerves, and the condition is called retro-bulbar neuritis. 